\title{
Legal Integration in the Andes: Law-making by the Andean Tribunal of Justice
}

\author{
Karen J. Alter \\ Laurence R. Helfer \\ Northwestern University \\ Duke University School of Law
}

\begin{abstract}
The Andean Tribunal of Justice (ATJ) is a copy of the European Court of Justice (ECJ), and the third most active international court. This article reviews our findings based on an original coding of all ATJ preliminary rulings from 1984 to 2007, and over forty interviews in the region. We then compare Andean and European jurisprudence in three key areas: whether the tribunals treat the founding integration treaties as constitutions for their respective communities, whether the ATJ and ECJ have implied powers for community institutions that are not expressly enumerated in the founding treaties, and how the tribunals conceive of the relationship between community law and other international agreements that are binding on the Member States.
\end{abstract}

\section{Introduction}

In 1969 Chile, Bolivia, Colombia, Ecuador, and Peru agreed to create a common market intended to spur regional economic development. The five Andean member countries hoped that a regionwide market would attract foreign capital, increase each state's negotiating leverage, and induce investors to keep their profits in the region. ${ }^{1}$ The European Community (EC) model of integration fit with these larger objectives. Andean governments planned to create regional industrial programs where investments and jobs would be distributed according to differing needs of the member countries, thereby lessening economic disparities across the region. ${ }^{2}$

The Andean Pact's founding treaty, the Cartagena Agreement, ${ }^{3}$ largely copied EC institutions, including a 'Commission' of national executives that adopted Andean legislation

\footnotetext{
${ }^{1}$ W. P. Avery and J. D. Cochraine, 'Innovation in Latin American Regionalism: The Andean Common Market', (1973) 27(2) International Organisation 181 at 198-9.

${ }^{2}$ S. Horton, 'Peru and ANCOM: A Study in the Disintegration of a Common Market', (1982) 17 Texas International Law Journal 39 (Horton, 'Peru and ANCOM') at 44.

${ }^{3}$ Andean Sub-regional Integration Agreement, May 26, 1969, 8 International Legal Materials 910.
} 
(known as 'Decisions') and a regional administrative body (the 'Junta') that supervised the implementation of those Decisions. There were some key differences however. The original Andean Pact did not include a court, and Commission decisions were not directly applicable. ${ }^{4}$

The Andean integration process faltered from the outset. Member States relied on foreign direct investment to fuel regional industrial programs and the substitution of imports. Yet the Andean Pact heavily regulated the transfer of technology and repatriation of profits, which discouraged potential investors and angered pro-business domestic elites. In the 1970s, the Andean Pact's investment code was the subject of multiple challenges, including two raised in Colombian courts. ${ }^{5}$ The efforts to dislodge this contested law raised fundamental questions about the legality of Andean Decisions within the Member States' national legal systems. For example, the Colombian lawsuits called into question the supremacy of Andean rules in Colombia and the validity of Andean rules implemented by means of presidential decrees. ${ }^{6}$ The drive to create an Andean Tribunal of Justice (ATJ or the Tribunal) expressly modelled on the European Court of Justice (ECJ) emerged from these varied challenges. ${ }^{7}$

Although the Member States endorsed the supranational legal system in principle, political concerns hindered the system's ability to function in practice. Bowing to pressure from national governments, the Junta initially refused to file cases with the Tribunal. As we explain elsewhere, two key changes brought the ATJ closer to emulating the ECJ model in form and in operation. First, in the 1990s the Member States repudiated the import substitution approach to Andean integration and replaced it with a policy favouring free trade and economic liberalisation — a change reflected in renaming the Pact as the 'Andean Community'. In anticipation of joining the World Trade Organisation (WTO), Andean governments adopted a set of regional intellectual property rules, which activated the link between national courts, national intellectual property agencies, and Andean judges and officials. Second, in 1996 Andean officials adopted a series of institutional reforms intended to make the ATJ more effective. ${ }^{8}$

Since these events, the ATJ has become the third most active international court, with over 1700 rulings by the end of 2009. This article expands on earlier publications by the authors

\footnotetext{
${ }^{4}$ Horton, 'Peru and ANCOM' at 44, op cit n 2 supra.

${ }^{5}$ Ibid at 44-51. On the Colombian court rulings, see L. W. Thomas, 'The Colombian Supreme Court Decision on the Andean Foreign Investment Code and Its Implications for the Law of Treaties', (1973) 8 Journal of International Law and Economics 113 (Thomas, 'The Colombian Supreme Court Decisions on the Andean Investment Code').

${ }^{6}$ Horton, 'Peru and ANCOM', op cit n 2 supra, at 51 and Thomas, 'The Colombian Supreme Court Decisions on the Andean Investment Code', op cit n 5 supra, at 117-119.

${ }^{7}$ Scott Horton notes that conflict raised by the Colombian court ruling served to 'peak demand in the community for a tribunal.' Horton, 'Peru and ANCOM', op cit n 2 supra, at 51. We discuss these developments further in K. J. Alter, L. Helfer and O. Saldias, 'Transplanting the European Court of Justice: The Founding of the Andean Tribunal of Justice', unpublished working paper (2011) (Alter et al, 'The Founding of the Andean Tribunal of Justice').

${ }^{8}$ For details see K. Alter and L. Helfer, 'Nature or Nurture: Judicial Law-making in the European Court of Justice and the Andean Tribunal of Justice', (2010) 64(4) International Organisation 563. Definition at 566.
} 
to compare ATJ law-making to that of the ECJ. Our interest in the ATJ is twofold. We want to understand whether and how the ATJ has facilitated legal integration in the Andean Community, and the extent to which the European experience has influenced that integration's trajectory. In an earlier paper, we focused on expansionist international judicial law-making, which we defined as occurring when international courts identify new legal constraints not found in treaty texts or in the intentions of their drafters, and when these constraints narrow state discretion. In this article, we augment our previous brief discussion of ATJ law-making in decisions issued in response to preliminary references from national courts. ${ }^{9}$ We begin by summarising the main findings of our published research on the Andean legal system. We then focus on three legal issues where ATJ has deviated from the jurisprudential path pioneered by the ECJ. In particular, we examine the extent to which the ATJ conceives of the Cartagena Agreement as a constitutional charter for the Andean Community, discuss the doctrine of implied powers, and briefly review the case law on the relationship between Andean law and other international agreements.

\section{The Andean Legal System: Key Findings from Our Research}

The ATJ is one of eleven functioning copies of the ECJ, and the most active of these. ${ }^{10}$ Our analysis of ATJ litigation patterns suggested that the two Community courts have many experiences in common. Both the ATJ and ECJ experienced a growing demand for preliminary rulings over time. Indeed, for both courts, preliminary rulings far outstrip other types of cases, especially in their early years of operation. In addition, both courts used early preliminary rulings to assert the direct effect and supremacy of Andean law. ${ }^{11}$ Our analysis focused on preliminary references to the ATJ because such cases were the principal mechanism for private litigants to access the ECJ. ${ }^{12}$ Together with Maria Florencia Guerzovich, we coded all 1338 preliminary rulings available on the Andean Community website from the ATJ's founding through 2007. Where the ATJ broke new legal ground, we analysed its decisions in depth. We also conducted

\footnotetext{
${ }^{9}$ Ibid.

${ }^{10}$ For more on ECJ copies see K. J. Alter, 'The Global Spread of European Style International Courts', Manuscript under review (2011).

${ }^{11}$ L. Helfer and K. Alter, 'The Andean Tribunal of Justice and its Interlocutors: Understanding the Preliminary Ruling Reference Patterns in the Andean Community', (2009) 42(4) Journal of International Law and Politics 871 at 888 .

${ }^{12}$ We compare the first twenty-five years of the European Economic Community (1960 and 1985) to the first twenty five years of the ATJ's operation (1984-2007). In these time periods, the ECJ issued 305 non-compliance decisions and 1808 preliminary rulings (an average of 86.1 cases per year), whereas the ATJ, with a geographically and demographically smaller region to oversee, issued 85 non-compliance decisions and 1338 preliminary rulings between 1984 and 2007 (an average of 71.5 per year). ECJ data from A. Stone Sweet, The Judicial Construction of Europe (Oxford University Press, 2004), at 72-79. For ATJ litigation patterns, see ibid.
} 
over forty interviews with lawyers, judges, and government officials in Peru, Ecuador, and Colombia, which led us to examine some noncompliance decisions as well. This section summarises our key findings about demand for preliminary rulings in the Andean Member States.

First, the subject matter of ATJ preliminary rulings is highly skewed; 96\% of all 1338 rulings involve intellectual property disputes. The domestic origin of these decisions is also remarkably uniform: 1285 cases began as challenges to an administrative agency's decision to grant or deny an application to register a trademark, patent or other intellectual property right. The lopsided nature of the ATJ's docket contrasts with the ECJ's significantly more varied docket in the first twenty-five years of the European common market. ${ }^{13}$

These differences partly reflect the fact that the EC has enacted common policies covering a broader range of issues, such as social security rules for migrant workers, gender discrimination, and agricultural policies. But they also reflect the markedly different usage of the two Community courts by private litigants. In the 1960s, German plaintiffs invoked the Treaty of Rome to challenge German turnover equalisation taxes at a time when there was no Community tax policy. ${ }^{14}$ Italian litigants invoked EC law to challenge the nationalisation of the Italian energy industry. ${ }^{15}$ In France, litigants invoked European law to challenge a government-sponsored association of gas stations and its grant of an exemption for imported semolina. ${ }^{16}$ In these and other cases, individuals and private firms invoked European law to challenge government policies they disfavoured. We found very few similar cases in the Andean legal system. Unlike in Europe, private litigants have rarely invoked Andean rules to challenge national laws that do not directly relate to the implementation of Community policies.

Second, we found that domestic intellectual property agencies have been the ATJ's primary interlocutors. Our research revealed that the agencies encouraged references to the ATJ and regularly consulted and incorporated Andean rulings in their decision-making. ${ }^{17} \mathrm{We}$ investigated why only intellectual property agencies became ATJ interlocutors. We found that these agencies were reorganised in the 1990s as part of a larger wave of government reforms and

\footnotetext{
13 Ibid at 894-895.

${ }^{14}$ Case 358/64, ‘Lutticke’ Firma Alfons Lütticke GmbH, Köln-Deutz: FG Saarland Lütticke case, FG II 357 (decision of 15 November 1966).

${ }^{15}$ Italian Constitutional Court, Costa v. E.n.e.l. \& Soc. Edisonvolta (Decision 14 of 7 March 1964), [1964] CMLR 425.

${ }^{16}$ Société des pétroles Shell-Berre et autres, Sociétés "Les Garages de France", Société Esso-Standard, Société Mobile Oil française, Société française des pétroles B.P.(Conseil d’État decision of 19 June 1964), [1964] Recueil Lebon 344, [1964] 5 R.D.P. 1019. Syndicat General de Fabricants de Semoules de France (Conseil d'État decision of 1 March 1968), [1968] Recueil Lebon 149, [1970] CMLR 395.

${ }^{17}$ L. Helfer, K. Alter and M. F. Guerzovich, 'Islands of Effective International Adjudication: Constructing an Intellectual Property Rule of Law in the Andean Community', (2009) 103 American Journal of International Law 1 (Helfer et al, 'Constructing an Intellectual Property Rule of Law in the Andean Community') at 21-25.
} 
policy changes associated with the Washington Consensus. ${ }^{18}$ The agencies were staffed by lawyers who had trained in Europe and the United States, provided with material and technical support from the World Intellectual Property Organisation, and funds from the registration of patent and trademarks. Taken together, these developments allowed the agencies to become professionalised, self-funding, and independent.

In addition, Andean intellectual property law was a new and technical subject about which domestic judges, law professors, and government officials had limited knowledge. The agencies thus turned to Andean Community officials and to each other as they addressed new and complex issues of intellectual property law. Andean officials worked with the agencies to interpret existing laws and to update regional rules. Over time, Andean intellectual property Decisions increasingly reflected the input and goals of national administrators, who then had a stake in seeing them implemented.

Third, unlike their European counterparts, national courts in the Andean Community rarely send novel or precedent-expanding questions to the ATJ. In our interviews, litigants and potential litigants expressed doubt that national judges and the ATJ would respond favourably to creative invocations of Andean law. The empirical record supports these sentiments. Almost all preliminary references from national courts involve issues where the applicability of Andean law was clear. We further found that national judges are mostly passive intermediaries situated between the ATJ and domestic administrative agencies charged with protecting intellectual property. We then probed in detail the nearly three dozen cases that did not involve intellectual property. Here too we found that national judges were mostly passive. We associated the lack of national judicial mobilisation with structural factors within national judiciaries, such as the lack of legal hierarchies in small countries and the fact that judges rotate position often and mainly repeat what their predecessors have done. But we also found few national judges with any personal connection to with the Andean integration process. ${ }^{19}$

Fourth, although the Andean integration project is now over forty years old, few lawyers and law professors have mobilised in support of Andean law. In contrast, as early as the 1960s the EC had an active community of advocates, subsidised in part by the European Commission, which helped create and pay for legal associations, law journals, dissertations, professorships,

\footnotetext{
18 The 'Washington Consensus' is the name given to a set of liberal economic policies that Americans and international institutions located in Washington diffused via International Monetary Fund conditionality and links to aid provision. For a discussion of this consensus, see J. Williamson, 'What Washington Means by Policy Reform', in J. Williamson (eds), Latin American Adjustment: How Much has Happened? (Institute for International Economics, 1990), at 7-20.

${ }^{19}$ These differences are discussed in: L. Helfer and K. Alter, 'The Andean Tribunal of Justice and its Interlocutors: Understanding the Preliminary Ruling Reference Patterns in the Andean Community', (2009) 42(4) Journal of International Law and Politics 871.
} 
and conferences. ${ }^{20}$ The Andean Community has a university (the Símon Bolívar Andean University), and lawyers who have worked for the General Secretariat sometimes teach courses in Andean law at universities in the region. With the exception of intellectual property, however, we found no network of scholars and practitioners that actively research and write about Andean law. Nor were there specialised journals, let alone a scholarly subfield, devoted to Andean law. ${ }^{21}$

Fifth, the above findings have persisted even as political support for Andean and European integration has waxed and waned over time. Scholars analysing ECJ law-making have argued that the ECJ became an expansionist law-maker when Member States' support for integration was blocked. ${ }^{22}$ In contrast, although the ATJ, like the ECJ, developed its key doctrines during its foundational period, subsequent ATJ rulings have tended to echo rather than counter-balance political support for integration. The Washington Consensus period of the early to mid-1990s — arguably Andean Community’s heyday — saw the adoption of detailed intellectual property laws and a common external customs union, and an upswing in national court referrals to the ATJ. The Tribunal adopted purposive interpretations of Andean intellectual property rules during this period. But it did not develop a body of case law on customs rules, nor did it become markedly more expansionist generally. Conversely, recent political crises—which climaxed in Venezuela's withdrawal from the Andean Community in 2006 - have not noticeably affected the content of preliminary rulings. The ATJ has continued to issue mostly narrow, technical rulings interpreting regional intellectual property rules. But it has also reaffirmed established precedents, even when doing so required confronting national governments. ${ }^{23}$

\section{The Different Jurisprudential Paths of the ECJ and ATJ}

Thus far, we have summarised our findings regarding the demand for Community rules and litigation before Community courts. This section discusses three general issues where the ATJ was presented with an opportunity to emulate ECJ doctrines but declined to do so. We explore

\footnotetext{
${ }^{20}$ K. J. Alter, The European Court's Political Power: Selected Essays (Oxford University Press, 2009), at 82-88 (Alter, The European Court's Political Power).

${ }^{21}$ Lawyers and academics publish newsletters and a specialised legal journal regarding Andean IP law-the Anuario Andino de Derechos Intelectuales.

${ }^{22}$ It is hard to assess the quantity of law-making, but most studies of ECJ law-making identify continuity over time suggesting that there is no significant retreat from law-making despite bouts of Euro-scepticism. See A. Stone Sweet, 'Constitutional Courts and Parliamentary Democracy', (2002) 25(1) West European Politics 77, R. Cichowski, The European Court and Civil Society: Litigation, Mobilization and Governance (Cambridge University Press, 2007), M. P. Maduro, We the court: the European Court of Justice and the European Economic Constitution: a critical reading of Article 30 of the EC Treaty (Hart Publishing, 1998).

${ }^{23}$ K. Alter and L. Helfer, 'Nature or Nurture: Judicial Law-making in the European Court of Justice and the Andean Tribunal of Justice', (2010) 64(4) International Organisation 563 at 578-80.
} 
the broader legal and political context of the cases in an effort to understand why the ATJ chose a different path and how the existence or absence of domestic demand for ATJ rulings affected the interpretive choices of Andean judges. This analysis, although necessarily somewhat speculative, is nonetheless suggestive of how the ATJ has selectively used the ECJ's jurisprudence and experience to adapt European rulings to the Andean context.

A Constitutionalisation of Community Treaties

Early ATJ decisions reveal that the founders of Andean legal system intentionally copied Community law doctrines that the ECJ has developed. When the ATJ issued its first preliminary ruling in 1987, it used the opportunity to explain the operation of the Andean legal system. The case did not involve the supremacy of Andean law. But the ATJ nonetheless stressed that Member States had declared the "full validity" of the following legal principles:

a) the legal system of the Cartagena Agreement has its own identity and autonomy, constitutes a common law and is part of the national legal systems, b) the legal system of the Agreement prevails within the framework of its competences, over the national norms, without unilateral acts or measures from the Member Countries being able to oppose this legal system, c) the Decisions implying obligations for the Member Countries come into effect on the date indicated. ${ }^{24}$

The ATJ thus indicated its implicit understanding that transplanting the ECJ model encompassed two foundational doctrines of European law - the supremacy of Community rules and their direct effect within national legal orders. ${ }^{25}$ The Tribunal also explained its relationship to national courts, underscoring both its exclusive competence to interpret Andean law and national judges' exclusive power to apply that law to the facts of the case. This division of authority mirrored the plain language in the ATJ Treaty. By reiterating this language, the ATJ may have been trying to reassure national judges that the Tribunal would not encroach into their exclusive domainsomething that the ECJ had repeatedly done in practice if not in principal. ${ }^{26}$

In its second preliminary ruling, the ATJ reiterated that Andean rules have primacy over conflicting domestic law, and it seemingly incorporated the ECJ's Simmenthal doctrine, which asserts that national judges must give European law priority even when it conflicts with domestic laws enacted later in time. The ATJ noted:

As far as the effect of the norms of integration on national norms, the doctrine and jurisprudence

${ }^{24}$ ATJ, Ruling 1-IP-87, at 3.

${ }^{25}$ Alter et al, 'The Founding of the Andean Tribunal of Justice', op cit $\mathrm{n} 7$ supra.

${ }^{26}$ See F. Mancini, 'The Making of a Constitution for Europe', (1989) 24 Common Market Law Review 595 at 606. 
indicate that, in the case of conflict, the internal rule will be superseded by the community one, which will be applied preferentially, since the competence in such a case corresponds to the community. In other words, the internal norm becomes inapplicable, to the benefit of the community norm. The [ECJ] has repeatedly given this indication (see principally the Costa/ENEL Sentences of June 15, 1964, and the Simmenthal Sentence of March 9, 1978) in agreement on this point with the spirit of the norms of the Andean integration. This effect of supersession of the national norm as a result of the application of preference, is especially clear when the later law which must have priority over the prior one, in accordance with universal principles of law - is precisely the community norm. ${ }^{27}$

Taken together, these rulings seemingly set the stage for the ATJ to follow in the ECJ's audacious footsteps. But the ATJ has not emulated the ECJ's strategy of making the Cartagena Agreement a higher order legal charter for the Andean Community. To illustrate the ATJ's different trajectory, we consider three classic examples in which the ECJ interpreted the Treaty of Rome as a mandate for judicial action to "constitutionalise" Community law and promote regional integration. First, the ECJ decided that treaty provisions prohibiting Member States from raising tariffs or enacting new trade barriers were immediately binding. ${ }^{28}$ Second, the ECJ declared that the treaty and sufficiently detailed secondary laws created direct effects within domestic legal orders. ${ }^{29}$ And third, it held that Community law was supreme to any conflicting prior or subsequent national rules and that national judges must not apply conflicting national laws. ${ }^{30}$ In each instance, the ECJ justified its interpretation of the treaty as necessary to realise the broad goals of Community legal order.

The doctrines that the ECJ developed were 'constitutional' in other respects. ${ }^{31}$ The ECJ used the rhetoric and decision-making style of a constitutional court. Its rulings invoke principles found in many national constitutions, such as higher order legal norms, individual rights, and structural questions relating to delegated powers. ${ }^{32}$ And by elevating core provisions of the

\footnotetext{
${ }^{27}$ ATJ, Ruling 2-IP-88 point 2, at 2-3.

${ }^{28}$ ECJ, Case 26/62, Van Gend en Loos v. Nederlandse Administratie Belastingen [1963] ECR 1.

${ }^{29}$ Ibid and ECJ, Case 41/74, Van Duyn v. Home Office [1974] ECR 1337.

${ }^{30}$ Italian Constitutional Court, Costa v. E.n.e.l. \& Soc. Edisonvolta (Decision 14 of 7 March 1964), [1964] CMLR 425. Amministrazione delle Finanze dello Stato v. Simmenthal SpA (II), ECJ Case 106/77, [1978] ECR 629, [1978] CMLR 263.

${ }^{31}$ Many scholars have mined the constitutional origins and nature of the ECJ's doctrine. A few examples include: J. Weiler, 'The Transformation of Europe', (1991) 100 Yale Law Journal 2403, E. Stein, 'Lawyers, Judges and the Making of a Transnational Constitution', (1981) 75 American Journal of International Law 1, M. P. Maduro, We the court: the European Court of Justice and the European Economic Constitution: a critical reading of Article 30 of the EC Treaty (Hart Publishing, 1998) at 8, A. Vauchez, 'Judge-made Law. Aux origines du modèle politique communautaire (retour sur Van Gend en Loos et Costa c. ENEL)', in O. Costa and P. Magnette, Une Europe des élites ? Réflexions sur la fracture démocratique de l'Union européenne (University of Brussels, 2007) at 139-166.

${ }^{32}$ For example, the ECJ, on its own authority, incorporated human rights protections into the EC. Weiler, ibid at
} 
Treaty of Rome above laws and decisions adopted by Member States and Community institutions, it made revision of those these laws far more difficult. This last feature expanded the court's power, since the only way to reverse an ECJ ruling interpreting the treaty was to convene an inter-governmental conference, adopt the new provisions by consensus, and have every Member State ratify them. The difficulty of this process, together with the recognition that intergovernmental conferences create opportunities for states to add other items to the agenda, meant that amendments were viewed as the "nuclear option-exceedingly effective, but difficult to use-and is therefore a relatively ineffective and non-credible means of Member State control" of the court. ${ }^{33}$

The ATJ has adopted strikingly different approaches when presented with similar legal issues. On several occasions, private litigants asked the Tribunal to follow the ECJ and interpret the Cartagena Agreement to impose immediate constraints on Member States. For example, litigants asked the ATJ to find that the treaty prohibited Colombia from imposing new duties on imports from Venezuela. The Colombian government argued that the Cartagena Agreement must be interpreted in conjunction with Andean Decisions, including those comprising the Andean Free Trade Program, suggesting that these Decisions had the effect of modifying the treaty. ${ }^{34}$ The ATJ agreed, reasoning that Member States had free reign to exclude items from the Free Trade Program notwithstanding the fact that the treaty envisioned the eventual adoption of broader free trade rules. ${ }^{35}$ In effect, the ATJ found that the Cartagena Agreement was not a fixed constitutional charter but only a starting point for integration that Member States could amend by adopting Andean secondary legislation. ${ }^{36}$

The ATJ has also relinquished some of its interpretive authority to national courts. For example, in a later case involving trade barriers that arose after a change in Andean law, the Tribunal considered which of three potentially applicable legal regimes governed the dispute. The ATJ defined the obligations under each regime. ${ }^{37}$ But rather than selecting the relevant rules

2417.

${ }^{33}$ M. Pollack, 'Delegation, Agency and Agenda Setting in the EC', (1997) 51(1) International Organisation 99 at 118-9.

${ }^{34}$ O. Saldias, 'Supranational Courts as Engines of Disintegration', Berlin Working Paper on European Integration No. 5 (Freie Universität Berlin, Dec. 2, 2007) at 12.

${ }^{35}$ ATJ, Ruling 1-IP-90, conclusion point 1.

${ }^{36}$ In a later nullification ruling the ATJ required that changes to the Cartagena agreement be adopted during a 'reunion de plenipotenciarios' and not via ordinary secondary legislation. See 1-AN-1996 points 2.4 \& 2.5. Another example is case 5-IP-89, in which the ATJ allowed governments to determine whether to prohibit foreign ownership in certain economic sectors.

${ }^{37}$ ATJ, Ruling 3-IP-93, point 2, at 7. The ATJ ruling suggested which legal regime applied, expecting the national judge would exercise its clear authority to apply Andean law to the facts of the case as the ATJ had indicated. In contrast, the ECJ has been far more willing to direct national judicial discretion while paying 'lip service to the language of the Treaty.' F. Mancini, 'The Making of a Constitution for Europe', (1989) 24 Common Market Law 
from among the three options, the ATJ left that key question for national courts to answer. ${ }^{38}$

In decisions involving Colombia's alcohol monopoly, the ATJ even appeared to back away from its earlier embrace of the ECJ's Simmenthal doctrine. In a non-compliance decision, the ATJ ruled that Colombia's implementation of alcohol monopoly violated Andean law. ${ }^{39}$ When the issue again reached the ATJ in the form of a preliminary reference from the Colombian Council of State, the ATJ reaffirmed that Colombia was obligated to modify practices that conflicted with Andean law. ${ }^{40}$ Yet the Tribunal refused to follow the next logical step in the Simmenthal doctrine-instructing national judges to do whatever was necessary to give effect to Community law. Instead, the ATJ simply reiterated what Andean law required without asking national judges to help it to enforce that law. Although the ATJ did not explain its reluctance to follow the ECJ, its ruling is difficult to divorce from the very real concern that national judges might find they lacked the legal authority or the political will to heed the ATJ's request. $^{41}$

Why has the ATJ been more reticent than the ECJ in demanding immediate compliance with the Cartagena Agreement? Although there are some differences in the applicable legal rules — such as the Andean Free Trade Program-law alone cannot explain why the ATJ is less willing to constitutionalise the treaty. In fact, both the Treaty of Rome and the Cartagena Agreement contain many similar features. They set broad and ambitious goals, such as promoting the well-being of citizens, contributing to development and prosperity, and building a common market. They define the competences of supranational legislative and administrative bodies and obligate states to work with these bodies to achieve the treaties' objectives. They include timetables for future action as well as immediately binding promises not to create additional trade barriers before the adoption of secondary legislation. And they both include a vague provision that requires Member States to ensure respect for Community rules within national legal orders. ${ }^{42}$

Review 595 at 606.

${ }^{38}$ ATJ, Ruling 3-IP-93, conclusions point 2: 'It is for the [national court] to determine whether the product in question is part of the Free Trade program of the Cartagena Agreement, the Nómina de Reserva [which forms part of Andean industrial programs] or the list of exceptions of the member country.'

${ }^{39}$ ATJ, Ruling 3-AI-97.

${ }^{40}$ ATJ, Ruling 29-IP-98.

${ }^{41}$ Colombia has remained in breach of Andean law (Decision of Nov. 11, 1999 regarding Decreto 244 of 1906). This case is discussed in greater detail in K. Alter and L. Helfer, 'Nature or Nurture: Judicial Law-making in the European Court of Justice and the Andean Tribunal of Justice', (2010) 64(4) International Organisation 563,576577. Treaty Establishing the European Economic Community, Mar. 25, 1957, 298 U.N.T.S. 11 (1958) (Treaty of Rome).

${ }^{42}$ Article 5 of the original Andean Court treaty largely repeats Article 5 of the original Treaty of Rome. The ECJ used this provision to suggest that Member States had implicitly endorsed the notion that domestic courts should apply Community law over conflicting national law. See P. Pescatore, 'The Doctrine of "Direct Effect": an Infant 
One possible explanation of the ATJ's greater reticence, notwithstanding these similarities, is that many Andean Pact programs predated the ATJ's existence. It may thus have been too controversial for the Tribunal to overturn these longstanding policies such as the Free Trade Program. A second explanation relates to the basic premise of the region's early integration agenda. As previously noted, the Andean Pact's import substitution and regional industrial policies depended heavily on foreign investment that never materialised. The lack of progress in achieving these policies created a conundrum. Should a Member State be held to the Community's market liberalization goals even if it had not received the quid pro quo of industrial development assistance? Seen in this light, establishing a "list of exceptions" from the Free Trade Program was a transitional compromise that allowed member states to exempt politically sensitive products until a common external tariff existed and common industrial programs obviated the need for such protections. ${ }^{43}$ The "list of exceptions" was clearly in tension with the free trade provisions of the Cartagena Agreement, which prohibited new barriers to trade and required the progressive removal of existing barriers. But the political compromise that the Free Trade Program embodied was arguably necessary to keep the troubled integration project afloat, and the ATJ may have been unwilling to challenge it without clear authorization to do so.

As noted above, the constitutional status of the Treaty of Rome reflects the reticence of Member States to reopen fundamental tenets of the Treaty and the 'acquis communautaire'. ${ }^{44}$ By contrast, Andean governments have been more willing to revise the Cartagena Agreement. In a 1996 nullification case, the ATJ established clear criteria for Member States to revise the Agreement. The case involved exemptions given to Peru to derogate from certain free trade rules. The Junta did not like the derogations and it challenged them before the ATJ. The Tribunal received the case in late 1996 when the Member States were reconsidering Peru's situation, which they resolved the following year when they adopted the Sucre Protocol. ${ }^{45}$ With Peru's

Disease of Community Law', (1983) 8(3) European Law Review 155, P. Pescatore, 'La clarence du législateur communautaire et le devoir du juge', in G. Luke (eds.), Rechtsvergleichung, Europarecht und Staatenintegration: Gedächtnisschrift für Ldontin-Jean Constantinesco (Köln-Berlín-Bonn-München, 1983) at 559-580. Treaty Establishing the Court of Justice of the Cartagena Agreement, (1973) 18 International Legal Materials 1203 (ATJ Treaty).

${ }^{43}$ Article 55 of the original Cartagena Agreement allowed member states to designate a "list of exceptions"-goods that were to be temporarily excluded from the trade liberalization program. The temporary exemptions continued for many years because the member states failed to adopt a Common External Tariff, which was to be a precursor to a total liberalization of goods within the Andean Community. See García Amador, F. V. The Andean legal order: a new community law. (Oceana Publications, 1978) at 24-34.

${ }^{44}$ The 'acquis communautaire' is the term used to describe the established common law of the European Community.

${ }^{45}$ Sucre Protocol of July 30, 1997 amended a number of provisions of the Cartagena Agreement. It contained a 'transitory provisional chapter' stating that the Free Trade Area would become operational by the end of 2005, and it allowed Peru to negotiate with the Commission its entry into the common external tariff system. See 
status now settled, the Junta tried to withdraw its lawsuit. ${ }^{46}$ The ATJ, however, refused to dismiss the suit. ${ }^{47}$ In its ruling on the merits, the ATJ found that the Peruvian exemption violated the Cartagena Agreement, but that its illegality had been "purged” by the Sucre Protocol. In other words, the Decision did not need to be nullified because a valid law had already superseded it. In reaching this result, the ATJ distinguished between Decisions-which are Andean secondary legislation adopted by the Member States sitting as the Andean Commission-and treaty amendments, which are agreed to at a 'conference of plenipotentiaries' (reunion de plenipotenciarios). ${ }^{48}$ The Tribunal thus suggested that states cannot adopt Decisions that undermine the Cartagena Agreement and that any formal changes to the treaty must be made via a different amendment process.

Formally speaking, the process of amending the Cartagena Agreement via a reunion de plenipotenciarios is the same as that for amending the EC's founding charter: the heads of the Member States must meet to adopt the amendments, which must then be ratified by each state. ${ }^{49}$ As a formal matter, the ATJ thus appears to be following the ECJ in enforcing more onerous procedures to amend the Community's founding charter. In practice, however, convening a reunion de plenipotenciarios does not appear to be very difficult. There are fewer Member States in the Andean Community, no evidence of a reluctance to convene inter-governmental conferences, and no larger 'acquis' of normative commitments that national governments view as inviolable. In addition, the existence of powerful Executive branches means that domestic ratification of treaty amendments is essentially assured.

Considering the ATJ's rulings in this wider political context reveals that the Tribunal has allowed the Cartagena Agreement's political masters to set the pace of regional integration rather than itself serving as an engine for integration beyond what Community law unequivocally required. In doing so, the ATJ also implicitly chose not to build a broader base of authority by signaling to attorneys, interest groups, and litigants that it would be receptive to creative legal arguments to further treaty's aspirational goals.

http://www.comunidadandina.org/INGLES/normativa/ande trie4.htm for a copy of the Protocol. See http://www.comunidadandina.org/INGLES/press/press/np14-4-03b.htm for a summary of the Protocol's key achievements.

${ }^{46}$ The judges reasoned that Andean Decisions were 'public acts' and that there was a general interest in ensuring the validity of such acts notwithstanding the Junta's change of mind. See ATJ, Ruling 1-AN-1996, point 1.4.1.

${ }^{47}$ ATJ, Ruling 1-AN-1996, point. 2.2. In invoking the concept of 'public acts', the ATJ incorporated the national constitutional concept that even if a questionable law has been superseded, judicial review is still necessary because legal rights could have been violated during the period when the unconstitutional law was valid.

${ }^{48}$ ATJ, Ruling 1-AN-1996, points 2.4 \& 2.5.

${ }^{49}$ It isn't entirely clear what qualifies as a reunion de plenipotenciarios. Would a meeting of heads of states suffice? One difficulty in answering this question is that 'Decisions' are the formal label attached to all Andean laws, and it often isn't clear whether a 'Decision' was adopted at a reunion de plenipotenciarios, or in a Commission meeting. 
Another question faced by both the ATJ and ECJ was whether Member States could adopt national regulations in the absence of binding Community rules. The founding treaties did not answer this question. As we explain below, the ECJ readily implied powers in favor of the EC and barred states from occupying regulatory space that might later be filled by Community rules. The ATJ, in contrast, has been significantly more reluctant to imply authority not explicitly delegated to Andean institutions.

Joseph Weiler has identified a number of ways in which the ECJ recognised 'implied powers'. First, the court conferred authority on Community institutions where the Treaty of Rome was silent. Weiler referenced an ECJ decision that granted the Community the power to agree to treaties binding on Member States. To achieve this result, the court "sidestep[ped] the presumptive rule of interpretation typical in international law, that treaties must be interpreted in a manner that minimises encroachment on state sovereignty", instead, it "favoured a teleological, purposive rule drawn from the book of constitutional interpretation." 50

Second, the ECJ barred states from enacting any legislation on issues within the Community's exclusive competence. Weiler summarised the doctrines this way:

In a number of fields, most importantly in common commercial policy, the [ECJ] held that the powers of the Community were exclusive. Member States were precluded from taking any action per se, whether or not their action conflicted with a positive measure of Community law. In other fields, the exclusivity was not an a priori notion. Instead, only positive Community legislation in these fields triggered a preemptive effect, barring Member States from any action, whether or not in actual conflict with Community law, according to specific criteria developed by the court. Exclusivity and pre-emption not only constitute an additional constitutional layer on those already mentioned but also have had a profound effect on Community decision making. Where a field has been pre-empted or is exclusive and action is needed, the Member States are pushed to act jointly. ${ }^{51}$

The ATJ has approached similar issues of Community authority with far more deference to the Member States. In a 1988 preliminary ruling, it adopted the principle of complemento indispensable: even in areas where Andean law clearly governs, Member States may enact domestic laws necessary to implement a Community rule provided that those laws do not

\footnotetext{
50 J. Weiler, 'The Transformation of Europe', (1991) 100 Yale Law Journal 2403, 2416. Weiler is primarily discussing the ECJ's decision in ECJ, Case 22/70, Commission v. Council (ERTA) [1971] ECR 263.

${ }^{51}$ Ibid at 2416.
} 
obstruct or nullify that rule. ${ }^{52}$ In a 1990 judgment, the ATJ further cabined the pre-emptive force of Andean law. It stressed that integration is a gradual, incremental process that limits the extent to which Community rules pre-empt national authority even in subject areas where Andean competence was extensive: "Especially, when dealing with complex and vast issues, such as intellectual property, . . . it seems logical that many of these diverse issues, even if they have to be a matter of common regulation in the beginning, are still within the competence of the national legislator for an indefinite time until they are effectively covered by the Community norms." 53

The ATJ has also coupled its recognition of shared legislative authority with deference to state actors to determine the boundaries between Andean and national authority. In a 1989 decision involving the revised Andean investment code, the ATJ underscored that Member States could not change the ownership rules for industries that had been nationalised as part of Andean industrial programs. ${ }^{54}$ But it did not claim certain industrial sectors as principal domains of Andean law, nor did it assert exclusive Community competence over the regulation of foreign investment. Instead, it gave to member governments 'full authority' to decide which economic sectors were reserved for domestic ownership. ${ }^{55}$

As noted above, the ECJ has been quite willing to imply powers and direct national judges in their application of European law. ${ }^{56}$ The government officials who drafted the ATJ's charter were seemingly aware of the ECJ's reputation, since they wrote the following into the ATJ's founding treaty: “The [Tribunal's] interpretation [in preliminary rulings] must be limited to specifying the contents and scope of the rules of the legal system governing the Cartagena Agreement. The [Tribunal's] may neither interpret the contents and scope of municipal laws nor determine the merits of matters concerning the proceeding." 57 The ATJ has strictly adhered to this provision. This 'hands off' approach makes it extremely difficult for private litigants to use the Andean legal system to challenge national laws and regulations. Such deference might have been defensible in the Tribunal's early years. But when adopting the 1996 Cochabamba Protocol, Member States authorised the ATJ to consider the facts of preliminary references and thus, implicitly, to guide the application of Andean law by national courts. ${ }^{58}$ Yet our review of all

\footnotetext{
${ }^{52}$ ATJ, Ruling 2-IP-88, point 3.

53 ATJ, Ruling 2-IP-90, point 1.

${ }^{54}$ T. A. O'Keefe, 'How the Andean Pact Transformed Itself into a Friend of Foreign Enterprise', (1996) 30(4) International Lawyer 811 at 818.

${ }^{55}$ ATJ, Ruling 5-IP-89.

${ }^{56}$ F. Mancini, 'The Making of a Constitution for Europe', (1989) 24 Common Market Law Review 595 at 606.

${ }^{57}$ ATJ Treaty, op cit n 42 supra. See Article 30.

${ }^{58}$ States amended what became Article 34, adding the italicised sentence: 'The Court's interpretation must be limited to specifying the contents and scope of the provisions comprising the legal system of the Andean
} 
preliminary rulings through 2007 disclosed only one decision, from 1998, where the ATJ delved into the facts of the case. ${ }^{59}$ In all other preliminary rulings, the ATJ limited itself to an abstract explication of Andean law.

In sum, our analysis reveals that the ATJ has rarely implied power for the Andean Community institutions or for itself. Instead, the Tribunal follows the traditional public international law practice of interpreting the absence of delegated authority as a retention of Member State prerogatives. The result is that, with the partial exception of intellectual property, ATJ preliminary rulings have only limited practical effect in constraining state action.

C The Relationship between Andean Law and International Treaties

There is one area, however, where the ATJ appears to have been more willing to assert the authority of Andean law. In the first non-compliance case, the Andean Secretariat challenged a bilateral agreement between Ecuador and the United States that required Ecuador to grant patent protection to certain drugs previously patented elsewhere. Ecuador's Parliament never ratified the treaty, but its President adopted a decree to implement it, and Ecuador's intellectual property office relied on the decree to award a number of domestic patents to foreign pharmaceutical companies. When the Secretariat challenged these patents before the ATJ, Ecuador defended the decree as falling within the discretion reserved to Member States to adopt domestic legislation or international agreements that "strengthen the industrial property rights provided for in" Andean law. ${ }^{60}$ The Tribunal categorically rejected Ecuador's claim that "an international commitment [could] be invoked as a reason to validate non-compliance with a prior Community obligation.”61 The decision did not expressly address the supremacy of Andean agreements over other international treaties, but it did suggest that Andean law - even secondary Andean law - trumps bilateral agreements.

A number of later rulings raised the question of whether WTO treaty obligations trumped Andean rules. Here we discuss only two. In a 2001 non-compliance decision, Ecuador and

Community, which refer to the specific case. The Court may neither interpret the contents and scope of national law, nor judge the facts in dispute. Even so, it may refer to those facts when essential for the requested interpretation.' For more on the Cochabamba changes see Alter et al, The Founding of the Andean Tribunal of Justice' op cit $n 7$ supra.

59 The case concerned Venezuela's implementation of a common Andean policy that aimed to strengthen the competitiveness of the Andean shipping industry. The ATJ found the facts provided by the national court to be insufficient, and it added to them by chronicling the plaintiff's efforts to convince the Venezuelan government to help achieve the Andean policy. The ATJ made clear that Venezuela was required to exclude access to ships from countries that do not grant reciprocal access to Andean ships. See ATJ, Ruling 19-IP-98.

${ }^{60}$ Article 143 of Decision 344.

${ }^{61}$ Id. This case is discussed in Helfer et al 'Constructing an Intellectual Property Rule of Law in the Andean Community’ op cit n 17 supra at 26-28. 
Venezuela invoked the Agreement on Trade-Related Aspects of Intellectual Rights (TRIPS) to defend a decision to grant a 'second use' patent for Viagra. Andean rules categorically reject second use patents, stating that "[p]roducts or processes already patented and included in the state of the art ... may not be the subject of new patents on the sole ground of having been put to a use different from that originally contemplated by the initial patent." 62 The ATJ stressed that the obligations undertaken by Member States, either as a matter of domestic or international law, cannot diminish or contradict Andean law, thereby indicating that Community rules prevail over multilateral as well as bilateral treaties. ${ }^{63}$

A later preliminary ruling involved a contract dispute between two private firms relating to foreign investment. The defendant invoked the General Agreement on Trade in Services (GATS) as a defence, suggesting that that WTO treaty governed the dispute. An Ecuadorian judge asked the ATJ to decide which law to apply. The ATJ again relied on the "autonomy of Andean law" to assert that Community rules are supreme to international treaties:

By virtue of its autonomy, it is confirmed that the Community legal order, both primary and secondary, is neither subordinate to domestic law or to the international sources of such countries. Consequently, international treaties concluded by the Member Countries on their own initiative, such as the TRIPS Agreement, does not bind the Community or have direct effect on it, without prejudice to the binding force of such instruments in the relationship between those member countries and third countries or international organisations. ${ }^{64}$

The ATJ's position makes eminent sense. Andean law could easily be undermined if international agreements ratified by Andean governments trumped conflicting Andean rules.

The ECJ has also considered the relationship between Community rules and WTO law. In contrast to the ATJ, however, the ECJ has refused to decide whether WTO treaties trump Community rules. For example, when Germany invoked the General Agreement on Tariffs and Trade (GATT) to challenge the EC's banana imports regime, the ECJ did not resolve the compatibility of the two legal regimes. ${ }^{65}$ Rather, it held that the WTO Agreements were generally not entitled to direct effect and could not be invoked to challenge the lawfulness of a

\footnotetext{
${ }^{62}$ Article 21 of Decision 486; Article 16 of Decision 344.

${ }^{63}$ See ATJ, Ruling 01-AI-2001 at 39 (judgment against Venezuela); ATJ, Ruling 34-AI-2001 at 51-52 (judgment against Ecuador).

${ }^{64}$ ATJ, Ruling 158-IP-2006, part C. In this passage, the ATJ quoted from and cited to prior cases involving TRIPS, which it then applied to GATS.

${ }^{65}$ ECJ, Case 280/93, Germany v. Council of the European Union [1994] ECR I-4973. Germany raised the argument again in a later case, where the ECJ reiterated this position. See Opinion 3/94 on the Framework Agreement on Bananas, [1995] ECR I-4577.
} 
Community act. ${ }^{66}$ When private litigants later invoked GATT provisions to challenge the banana regime, the ECJ held its ground. The case also reached the German Constitutional Court, which refused to reverse the ECJ. The result was a stalemate: as a formal matter, the hierarchical relationship between Community law and WTO treaties remained unresolved, but as a practical matter litigants are unable to invoke the treaties to challenge Community law. ${ }^{67}$

The hierarchy issue also featured prominently in the ECJ's 2008 ruling in the Kadi case, which concerned a challenge to an EC regulation adopted to implement a United Nations Security Council resolution that ordered states to freeze the assets of certain suspected terrorists. ${ }^{68} \mathrm{~A}$ key issue in the case was whether the ECJ was precluded from reviewing the validity of the regulation because, pursuant to the UN Charter, the Security Council resolution on which it was based trumped other international agreements. ${ }^{69}$ Reasoning that "the obligations imposed by an international agreement cannot have the effect of prejudicing the constitutional principles of the EC Treaty”, the ECJ stated:

[I]t is not a consequence of the principles governing the international legal order under the United Nations that any judicial review of the internal lawfulness of the contested regulation ... is excluded by virtue of the fact that that measure is intended to give effect to a resolution of the Security Council adopted under Chapter VII of the Charter of the United Nations. What is more, such immunity from jurisdiction for a Community measure ...., as a corollary of the principle of the primacy at the level of international law of obligations under the Charter of the United Nations $\ldots$, cannot find a basis in the EC Treaty. ${ }^{70}$

Although scholars continue to debate the significance of Kadi, the judgment confirms the autonomous nature of EC law-and its de facto supremacy over other international agreements—in terms that echo the ATJ's earlier rulings.

\footnotetext{
${ }^{66}$ ECJ, Germany v. Council of the European Union, ibid paras. 109-112; see also P. Eeckhout, 'Judicial Enforcement of WTO Law in the European Union--Some Further Reflections', (2002) 5 Journal of International Economic Law 91, 95.

${ }^{67}$ These cases are discussed in Alter, The European Court's Political Power, op cit n 20 supra at 222-223, and K. J. Alter, Establishing the Supremacy of European Law: The Making of an International Rule of Law in Europe (Oxford University Press, 2001) at 110-115.

${ }^{68}$ ECJ, Joined Cases C-402/05 P and C-415/05 P, Yassin Abdullah Kadi and Al Barakaat International Foundation v. Council of the European Union [2008] ECR I-6351 (Kadi).

${ }^{69}$ Article 103 of the UN Charter provides that '[i]n the event of a conflict between the obligations of the Members of the United Nations under the present Charter and their obligations under any other international agreement, their obligations under the present Charter shall prevail.'

${ }^{70}$ ECJ, Kadi, op cit n 68 supra, paras 299-300.
} 


\section{Conclusion}

This article has considered how the ATJ has both built upon and moved away from the ECJ, the regional supranational tribunal on which it was modelled. In early rulings, the ATJ invoked ECJ jurisprudence to establish Andean Community law as distinct from traditional international law. This was an important move, suggesting that international law doctrines were not appropriate for interpreting Community treaties and secondary legislation. Over time, however, the ATJ has shown more reticence than its European counterpart and has refused to serve as the engine of Andean legal integration. The Tribunal has defended unambiguous Andean laws against attempts by individual Member States and private litigants to undermine them. But it has readily allowed national governments to make collective decisions that have slowed the pace of integration or radically altered previously adopted Andean rules. The ATJ has also recognised the autonomy of national governments and national courts to decide how Andean law applies in the national context.

The ATJ's approach to these issues may be politically prudent, since both Member States and national judiciaries have fairly tepid commitments to Andean integration. Unlike in Europe, Andean governments have negotiated many exemptions from regional free trade rules and have even withdrawn from the Andean integration process. ${ }^{71}$ In reflection of this reality, ATJ judges have equivocated in their support of the key Community legal doctrines, recognising them only when doing so was consonant with the Member States' collective political will. As a constitutional order, therefore, the Andean legal system remains vulnerable to Member State decisions that compromise Community rules in favor of national political objectives.

\footnotetext{
${ }^{71}$ Chile withdrew in 1976 and Venezuela withdrew in 2006.
} 